\title{
"The determinants of corporate cash holdings levels: evidence from selected South African retail firms"
}

\begin{tabular}{|c|c|}
\hline AUTHORS & $\begin{array}{l}\text { Trust Chireka } \\
\text { Michael Bamidele Fakoya (D https://orcid.org/0000-0002-8763-0616 } \\
\text { R https://publons.com/researcher/2040164/michael-bamidele-mb-fakoya/ }\end{array}$ \\
\hline ARTICLE INFO & $\begin{array}{l}\text { Trust Chireka and Michael Bamidele Fakoya (2017). The determinants of } \\
\text { corporate cash holdings levels: evidence from selected South African retail firms. } \\
\text { Investment Management and Financial Innovations, 14(2), 79-93. } \\
\text { doi:10.21511/imfi.14(2).2017.08 }\end{array}$ \\
\hline DOI & http://dx.doi.org/10.21511/imfi.14(2).2017.08 \\
\hline RELEASED ON & Friday, 02 June 2017 \\
\hline RECEIVED ON & Friday, 03 March 2017 \\
\hline ACCEPTED ON & Wednesday, 26 April 2017 \\
\hline LICENSE & $\begin{array}{l}(c) \text { EY-NC } \\
\text { This work is licensed under a Creative Commons Attribution-NonCommercial } 4.0 \\
\text { International License }\end{array}$ \\
\hline JOURNAL & "Investment Management and Financial Innovations" \\
\hline ISSN PRINT & $1810-4967$ \\
\hline ISSN ONLINE & $1812-9358$ \\
\hline PUBLISHER & LLC "Consulting Publishing Company "Business Perspectives" \\
\hline FOUNDER & LLC "Consulting Publishing Company "Business Perspectives" \\
\hline
\end{tabular}

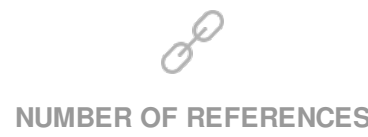

52
NUMBER OF FIGURES

0
NUMBER OF TABLES

4

C The author(s) 2023. This publication is an open access article. 


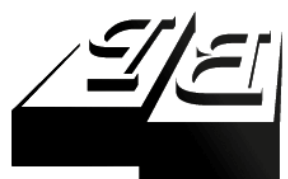

BUSINESS PERSPECTIVES

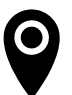

LLC “CPC "Business Perspectives” Hryhorii Skovoroda lane, 10, Sumy, 40022, Ukraine

www.businessperspectives.org

Received on: $3^{\text {th }}$ of March, 2017 Accepted on: $26^{\text {th }}$ of April, 2017

(C) Trust Chireka, Michael Bamidele Fakoya, 2017

Trust Chireka, Department of Financial Management, School of Accountancy, University of Limpopo, South Africa.

Michael Bamidele Fakoya, Africa Centre for Sustainability and Management (ACSAM), School of Accountancy, University of Limpopo, South Africa.

\title{
THE DETERMINANTS OF CORPORATE CASH HOLDINGS LEVELS: EVIDENCE FROM SELECTED SOUTH AFRICAN RETAIL FIRMS
}

\begin{abstract}
With corporate cash holdings on the rise, stakeholders need to know, among other things, what informs the companies' cash holding policies and whether there are any benefits to be derived from piling up these cash reserves. Studies conducted in developed countries have identified the following as determinants of corporate cash holdings: firm size, growth opportunities, liquid asset substitutes, capital expenditure, leverage, dividend payments, cash flows and cash flow volatility. Few studies have focused on what drives firms' cash holdings behavior in emerging economies. This study, the first of its kind, investigated the determinants of corporate cash holdings in the South African retail industry. The paper used panel data analysis to test the relationships between cash holdings level and the identified determinant factors. The authors found evidence that liquid asset substitutes, capital expenditure, dividend payments and cash flow volatility significantly influence the cash holdings levels of retail firms listed on the Johannesburg Stock Exchange.
\end{abstract}

\section{Keywords}

\section{JEL Classification}

\section{INTRODUCTION}

There has been a notable increase in corporate cash holdings levels. For example, recent reports showed that Apple and GM Motors were each holding more cash than the US treasury. But just how much cash is too much and what informs the decision on how much cash a firm should have in hand. This study investigated what determines the levels of cash holdings by retail firms listed on the Johannesburg Stock Exchange (JSE). Most literature on corporate cash holdings has also focused on the determinants of corporate cash holdings. For instance, Kim, Mauer and Sherman (1998) studied the determinants of cash holdings for some US companies and found that firms with higher costs of external financing, those with unstable earnings, together with businesses with relatively low returns on assets hold larger cash reserves. Opler, Pinkowitz, Stulz and Williamson (1999) found that small firms and those with good growth opportunities and volatile cash flows have high cash holdings. Much of these studies, however, have focused on Western countries with a few targeting on Asia (Kim, Kim and Woods, 2011; Islam, 2012; Horioka and Terada, 2013; Uyar and Kuzey, 2013; Fischer, Marsh, and Brown, 2014). While the cash
This is an Open Access article, distributed under the terms of the Creative Commons Attribution-NonCommercial 4.0 International license, which permits re-use, distribution, and reproduction, provided the materials aren't used for commercial purposes and the original work is properly cited. 
holdings phenomenon is not limited to the US, little research was conducted in African countries including South Africa. Therefore, this study investigates the determinants of cash holdings of the JSE listed firms in one of South Africa's leading economic sectors, the retail sector.

The inquiry of the drivers of the recently observed large corporate cash holdings has become a primary concern of both academics and practitioners (Boubaker, Derouiche and Nguyen, 2015). From a theoretical standpoint, corporate cash holdings can be explained by three models: trade-off theory, pecking order theory, and the agency theory. To a large extent, corporates are thought to be motivated to hold cash by either the transaction cost motive or the precautionary motives (Kim et al., 2011). Other purposes of holding cash include the tax motive and the speculative motive. This study seeks to close that gap and to encourage further research on the determinants of cash holdings for the firms operating in Africa, specifically South African retail firms. This study contributes to the existing corporate cash holdings literature by adding empirical evidence from an emerging South African economy into the ongoing discussion of cash holdings by firms.

However, studies have shown that South African companies are holding excessive cash for reasons that include unstable political climate, planned offshore investments, anticipated future investments and acquisitions and labor unrests in some sectors such as mining sector. Other reasons include anticipated peak selling season, lower interest rates at local banks, and increased capital needed to fund expansion plans into the rest of Africa (Mittner, 2013). Hence, this study investigates the firm-specific determinants of corporate cash holdings in the South African retail industry. Corporate liquidity policies are critical both in finance theory and the applied corporate world (Ali and Yousaf, 2013). Cash holdings come with advantages and disadvantages and firms are expected to hold an optimal level of cash that enhances shareholder value. With corporate cash holdings on the rise, there is a need to know what informs managers of different firms of the optimal levels to maintain. Stakeholders and users of financial information need to know what firm-specific characteristics justify the level of cash holdings.

\section{THEORETICAL PERSPECTIVE}

Cash reserves give firms much needed financial independence, thereby enabling them to follow their strategic trajectory with limited external interference (Boubaker et al., 2015). Furthermore, internally generated funds are cheaper than those externally sourced. As such, firms with sufficient cash in hand can investment in viable investment opportunities at a low cost of financing.

Stockpiling cash reserves, however, might unintentionally fuel inefficiencies involving the use of corporate resources. Ali and Yousaf (2013) argue that sufficient liquid assets afford managers the flexibility to use these resources even in negative net present value (NPV) projects. Recent studies (Faulkender and Wang, 2006; Dittmar and Mahrt-Smith, 2007) have confirmed Jensen's (1986) free cash flow hypothesis that an additional dollar that a firm holds is less than one dollar. Daher (2010) posits that underlying these findings is the assumption that excessive cash conceals the benefits of externally sourced funds as the monitoring tool, as well as allowing managers to extract personal advantages. Cash holdings, therefore, have both an upside and a downside so that firms need to maximize the former while minimizing the latter.

In perfect markets with no information asymmetry, taxes, and agency and transaction costs, companies have no need to hold cash, as there are no benefits or costs of allocating cash. When internal cash owned by the firm is not sufficient to meet the needs, the company can obtain external financing at fair prices that do not compromize growth and investment (Gomes, 2012). In such a frictionless world, cash holdings would have no effect on the firm value or shareholder wealth (Opler et al., 2001). Markets are, however, imperfect, and these imperfections cause external financing to be more expensive than internal resources. Therefore, in the real world of imperfect markets, corporate cash holdings are a strategic component of the business capital structure. Firms with peculiar circumstances should decide on their optimal cash holdings level. 
In the next section, we expound the three theories of cash holdings that have been used to explain the pattern of cash holdings across various industries. The same arguments are expected to be relevant even to the retail industry.

\subsection{Trade-off theory}

Per Afza and Adna (2007), management with a goal to maximize shareholder wealth should aim to achieve an optimal cash holdings level by weighing the marginal benefits and marginal costs of holding cash. The advantages of holding cash derive from the transaction cost motive and the precautionary motive (Boubaker et al., 2015). By holding cash, firms cut down on the transaction cost of raising funds from the capital markets. Furthermore, holding cash is a safeguard against difficult times when companies struggle to obtain funding from external sources (Myers and Majluf, 1984). Holding more cash, however, comes with a price, as businesses pay a liquidity premium in the form of the lower rate of return generated by these stored liquid assets. Shah (2012) posits that the main cost of holding cash is the opportunity cost of capital invested in liquid assets such as forfeited profitable investments (Ferreira and Vilela, 2004).

\subsection{The pecking order theory}

Contrary to the trade-off theory's assertion of the existence of an optimal level of cash holdings, the pecking order theory of Myers and Majluf (1984) envisages that because of the asymmetric information between firms and capital markets, external funds are more expensive for companies than internally generated funds. To avoid high borrowing costs, companies will prefer to utilize internal resources to finance investments before looking for external funds in this order: safe debt, risky debt and, lastly, if needed, equity (Ferreira and Vilela, 2004).

\subsection{The agency theory}

In financial management, the agency theory addresses the problems that often arise between the principal (shareholders) and the agent (management). The agent has the duty to act and conduct the firm's business in a way that maximizes shareholders' wealth. Researchers have found that, among other things, there can be a conflict between maximizing shareholders' wealth and maximizing management remuneration. Another conflict arises when the principal and the agent have contrasting risk outlooks (Dinh Pham Anh, 2013). Regarding corporate cash holdings, the agency theory includes two suppositions: a) the free cash flow hypothesis b) the risk reduction hypothesis.

\subsubsection{Free cash flow hypothesis}

The free cash flow hypothesis of Jensen (1986) objects to the existence of a target cash level. Per Harford (1999), corporate cash holdings are perceived as free cash flows, since they can be used to serve management's own interests at the expense of the shareholders. The free cash flow hypothesis, thus, envisages that managers are more inclined to stock up cash, as it increases the assets under their control. This, in turn, affords them more unrestricted investment prerogative. With a stockpile of cash, managers can relatively easily avoid the capital markets and do not have to comply with their transparency requirements regarding possible investments (Ferreira and Vilela, 2004). "Managers' selfish behaviors can include lavish spending on luxurious offices and unjustifiable mergers and acquisitions. Hence, excessive cash can create overinvestment problems, because they may be used to fund negative NPV projects" (Thanatawee, 2011. p. 53). This assertion agrees with the notion of Dittmar and Mahrt-Smith (2007) that shareholders ascribe an inferior value to a marginal dollar of cash reserves, when there is a greater probability of agency conflicts in a firm.

\subsubsection{Risk reduction hypothesis}

While the free cash flow hypothesis has received some coverage in the agency theory literature, only a few researchers have focused on the risk reduction hypothesis, namely Opler et al. (1999) and Tong (2006). The risk reduction hypothesis addresses the conflict that might occur when management and shareholders have different attitudes to risk. "Since corporate cash holdings can be viewed as risk-free investments, a risk-averse and self-interested CEO can allocate more firm assets to corporate cash holdings to reduce firm risk at the expense of giving up some positive NPV but risky projects, which is not beneficial to share- 
holders" (Tong, 2006, p. 3). In his study, Tong (2006) investigates how the CEO's risk incentives influence the level of a firm's cash holdings, where the CEO's risk incentive is measured by "the sensitivity of the value of executive stock options (ESO) to the volatility of stock returns" (Tong, 2006, p. 4). His findings were that firms with lower ESO risk incentives were holding more cash reserves, confirming the hypothesis that risk-averse and selfseeking managers will channel company assets to cash holdings with the effect of reducing firm risk in a manner that is detrimental to the shareholders.

\subsection{Motives of holding cash}

Further to the above theories, there are various other motives that influence firms to hold cash. The most outstanding, in literature, of these are the transaction motive, the precautionary motive, the tax motive and the speculative motive. These are discussed below.

\subsubsection{The transaction motive}

The transaction motive is a classic model for optimal demand for cash, which gained popularity in the 60s with the major proponents being Miller and Orr (1966). The reasoning behind this motive is that in a case where a firm does not have cash to meet its financial obligations or to invest in profitable projects, the company either should approach the financial markets or to dispose of noncash financial assets to raise the finance needed. The cash required to make these payments is the optimal demand for cash. Unfortunately, these fundraising transactions can incur significant costs (Bates et al., 2009). Saddour (2006) states that in a world of imperfect markets, a firm can circumvent transaction costs by increasing its cash holdings.

\subsubsection{The precautionary motive}

Companies tend to retain more cash if they anticipate future cash flows to be volatile and access to capital markets to be costly (Bates et al., 2009). Per Mikkelson and Partch (2003), if future cash flows are expected to be volatile, firms will increase their cash holdings as a way of hedging against future uncertainty. These differential cash holdings are known in the literature as precautionary cash holdings. Evidence by Almeida, Campello and
Weisbach (2004) suggests that the precautionary motive is more relevant to financially distressed firms than to their unstressed peers. Firms that anticipate future difficulties in raising funds for investments and operations tend to retain high cash holdings as a safeguard.

\subsubsection{The tax motive}

While the transaction motives and the precautionary motives have mostly been cited in the empirical literature to be driving corporate cash holdings, Foley, Hartzell, Titman and Twite (2007) found evidence that repatriation taxes in part influenced the cash holdings of US transnational firms. The US imposes taxes on the income earned from the foreign operations of local businesses, although they award tax credits for the foreign taxes paid on the foreign operations. In this study, Foley et al. (2007) found that US firms with foreign subsidiaries tend to hold the cash earned in the foreign subsidiaries to avoid taxes upon repatriation. These overseas subsidiaries will use their earnings to invest in positive NPV projects with the remainder of the earnings being kept as cash reserves. Foley, Hartzell, Titman and Twite (2007) found that firms exposed to greater tax burdens on repatriated earnings will hold more cash. Although the findings of Foley et al. (2007) apply to the US and many other countries, the South African tax laws are different.

\subsubsection{The speculative motive}

Sometimes firms arm themselves with cash piles in anticipation of future profitable investment opportunities (Kariuki, Namusonge \& Orwa, 2015). Although Yu, Lee, Yi and Fok (2015) find that previous period cash holdings by Chinese firms lead to increased speculative activities in the following year, the speculative motive of holding cash was also found to weaken, as the level of corporate governance improved. This is because, as the study explains, speculative activities are generally noncore and oftentimes unethical activities. As corporate governance is more pronounced in South Africa than in China due to the influence of institutional investors (Zhang, 2016), this study envisages that the speculative motive of cash holdings is negligent in South African firms. Again, the difficulty of identifying and measuring risk activities 
inhibits the possibility of empirically investigating the speculative motive of cash holdings (Yu, Lee, Yi and Fok, 2015).

\subsection{The determinants of cash holdings}

\subsubsection{Firm size and cash holdings}

The nexus between corporate cash holdings and firm size has been debated extensively in many studies. Per the trade-off theory, the relationship between firm size and cash holdings is negative. Bigelli and Sanchez-Vidal (2012) postulate that larger companies enjoy the economies of scale, which, in turn, enables these companies to secure external finance relatively quickly and cheaply. Moreover, more major companies utilize their economies of scale to lower transaction costs, which are fixed expenses incurred in external borrowing (Kim et al., 2011). Per Al-Najjar and Belghitar (2011), larger firms are more diversified than the smaller ones and so are less susceptible to bankruptcy cost. As transaction costs are lower for larger firms than smaller companies, firm size and cash holdings are expected to have an inverse relationship. The pecking order theory envisages a positive correlation between firm size and corporate cash holdings, as the former is viewed as a proxy for business success. Larger companies achieve growth through profitability and are likely to retain more cash after controlling for their investment needs (Ferreira and Vilela, 2004). Furthermore, the agency theory posits that larger firms have dispersed shareholders, allowing more autonomy to the managers to hold more cash for private perquisites (Ferreira and Vilela, 2004).

Empirical evidence supports the trade-off theory in explaining the association between firm size and corporate cash holdings. Our study, thus, envisages a negative relationship between firm size and cash holdings.

\section{H1: There is a negative relationship between firm size and cash holdings.}

\subsubsection{Leverage and cash holdings}

The trade-off theory postulates that high leverage exposes companies to financial distress and bankruptcy. Highly levered companies will, thus, have a precautionary motive to hold more cash to avert bankruptcy (Al-Najjar and Belghitar, 2011; Kim et al., 2011). In contrast, D’Mello et al. (2008) posit that leverage indicates a firm's ability to access the capital markets for more debt successfully. Consequently, highly levered firms (with high ability to obtain extra debt from the markets) will hold less cash. The trade-off theory is, therefore, inconclusive regarding the relationship between leverage and cash holdings. The pecking order theory argues that debt grows when a firm's investment needs surpass its retained earnings (Ferreira and Vilela, 2004). Therefore, highly levered firms will have less cash as their investment needs outweigh their cash-generating abilities, indicating a negative relationship between leverage and cash holdings. From an agency theory perspective, highly levered firms are less likely to hold high cash reserves because of the monitoring role of debt.

Although some researchers found a nonlinear relationship between leverage and cash holdings (Drobetz and Gruninger, 2007; Guney et al., 2007), most recent studies have found that highly levered firms tend to hold less cash (Al-Najjar \& Belghitar, 2011; Subramaniam et al., 2011; Uyar and Kuzey, 2014; Wasiuzzamam, 2014). In line with many prior studies, this study envisages a negative relationship between leverage and cash holdings.

H2: There is a negative relationship between leverage and cash holdings.

\subsubsection{Investment opportunities and cash holdings}

Per the pecking order theory, firms with high investment opportunities will hold more cash to lower the cost of financing these investments, since internally generated funds are cheaper than capital market financing (Kim et al., 2011; Bigelli and Sanchez-Vidal, 2012). On the other hand, the trade-off theory posits that firms with growth potential (investment opportunities) will be driven by the precautionary motive to hold more cash, as market constraints and financial distress will be costlier to such firms (Ferreira and Vilela, 2004; Kim et al., 2011). From an agency theory standpoint, low-growth 
firms (companies with fewer investment opportunities) but run by entrenched managers might still accumulate cash (Subramaniam et al., 2011). These managers will, in turn, use the cash holdings to invest even in negative NPV projects without being subjected to the scrutiny of the capital markets (Bates et al., 2009).

This study, however, follows the findings of most studies that found a positive relationship between investment opportunities and cash holdings (Guney et al., 2007; Al-Najjar and Belghitar, 2011; Wasiuzzaman, 2014).

H3: There is a positive relationship between investment opportunities and cash holdings.

\subsubsection{Liquid asset substitutes and cash holdings}

In the case of cash shortages, firms can convert their liquid assets into cash (Al-Najjar and Belghitar, 2011). Liquid assets can be turned into cash more cheaply than the other assets and can so help to avoid expensive capital market financing (Ozkan and Ozkan, 2004). The trade-off theory, thus, envisages a negative relationship whereby firms with higher liquid asset substitutes will hold fewer cash reserves. This relationship is supported almost unanimously in the literature (Bates et al., 2009; Gill et al., 2012; Bigelli and Sanchez-Vidal 2012; Uyar and Kuzey, 2014).

H4: There is a negative relationship between liquid asset substitutes and cash holdings.

\subsubsection{Capital expenditure and cash holdings}

Per the trade-off theory, capital investment mirrors financial distress (Bates et al., 2009). Therefore, firms with high capital investment will face higher financial distress costs in the capital markets. In their attempt to avoid these high transaction costs, such companies often hold more cash (Riddick and Whited, 2009). In contrast, capital expenditure usually results in the creation or the improvement of new assets that can be pledged by firms as collateral, thus, bolstering firms' borrowing capacity (Kim et al., 2011). Consequently, companies that have enhanced access to loans will hold less cash.
Although empirical evidence is inconclusive regarding the relationship between capital expenditure and cash holdings, this study hypothesizes a negative correlation, as found by Bates et al. (2009), Kim et al. (2011) and Iskandar-Datta and Jia (2012).

H5: There is a negative relationship between capital expenditure and cash holdings.

\subsubsection{Dividend payments and cash holdings}

Per the trade-off theory, a negative correlation exists between dividend payments and corporate cash holdings levels, because firms that pay dividends can trade-off the high costs of stocking cash by drawing down on dividend payments (Al-Najjar, 2013). Companies that pay dividends can more quickly raise capital at lower costs in times of need by cutting down on dividend payments (Al-Najjar and Belghitar, 2011). Drobetz and Gruninger (2007) posit that firms that pay dividends have better corporate governance mechanisms that, in turn, can raise capital at lower costs. Based on these arguments, this study hypothesizes that:

H6: There is a negative relationship between dividend payments and cash holdings.

\subsubsection{Cash flows and cash holdings}

The trade-off theory views cash flow as an alternative source of liquidity than can set managers free from the financial constraints that can otherwise be imposed by the capital markets (Hardin et al., 2009). Essentially, cash flows can be used in times of cash shortages, thus, negating the need to hold cash (Kim et al., 2011). The pecking order theory, however, proposes that firms with good cash flows will use these cash flows to finance their projects, pay off their debt and accumulate cash holdings. Therefore, companies with persistently high cash flows will have significant cash holdings.

While the two theories offer opposing views on the influence of cash flows on cash holdings, this study follows the most recent findings of Rehman and Wang (2015) and hypothesizes that:

\section{H7: There is a negative relationship between cash flows and cash holdings.}


1.5.8. Volatility of cash flows and cash holdings

High volatility of cash flows signifies uncertainty in future earnings and, as such, a higher probability of financial distress (Ozkan and Ozkan, 2004). Since firms in financial distress might be forced to forego viable investment opportunities, these companies will hold more cash in line with the trade-off theory. The trade-off theory, therefore, envisages a positive relationship between cash flow volatility and cash holdings. Empirical findings are consistent with the trade-off theory (Guney et al., 2007; Al-Najjar and Belghitar, 2011; Bigelli and Sanchez-Vidal, 2012).

In line with the trade-off theory, this study, thus, envisages that:

H8: There is a negative relationship between cash flow volatility and cash holdings.

\section{METHOD}

To understand and test the determinants of corporate cash holdings from the theoretical and empirical evidence, this study used panel data analysis in the manner of previous studies (Ali and Yousaf, 2013; Ali, Ullah and Ullah, 2016). The data for this study comprised observations on 17 retail firms listed on the JSE collected for the period from 2000 to 2015 . The data used to proxy the variables in this investigation were acquired from the INET BFA database. INET BFA is one of Africa's leading providers of financial data and analysis tools. We used Eviews software for the analysis of the panel data collected. Following the method used by Ali et al. (2016), we had three-panel data regression models run, namely, the pooled ordinary least squares (POLS) model, the fixed effects model, and the random effects model. The study further investigated the most appropriate model of the three using the likelihood test ratio and the Hausman test. The likelihood test ratio compared the POLS model with the fixed effects model, whereas the Hausman test compared the fixed effects model with the random effects model.
The equation below shows the model used in the estimation:

$$
\begin{aligned}
& C A S H_{i, t}=\alpha_{i t}+b_{1} S_{Z Z E_{i, t}}+b_{2} L E V_{i, t}+ \\
& +b_{3} M T B_{i, t}+b_{4} L I Q_{i, t}+b_{5} C E_{i, t}+ \\
& +b_{6} D P D_{i, t}+b_{7} C F_{i, t}+b_{8} V C F_{i, t}+u_{i, t}
\end{aligned}
$$

where $\alpha_{i t}$ is the intercept term, $S I Z E_{i, t}$ is firm size, $L E V_{i, t}$ is leverage, $M T B_{i, t}$ is investment opportunity, $L I Q_{i, t}$ is liquid asset substitutes, $C E_{i, t}$ is capital expenditure, $D P D_{i, t}$ is dividend payments, $C F_{i, t}$ is cash flows, $V C F_{i, t}$ is cash flow volatility and $u_{i, t}$ is the error term.

Table 1 below summarizes the variables above and how they were estimated.

\begin{tabular}{|c|c|c|}
\hline Variables & Code & Description \\
\hline \multicolumn{3}{|c|}{ Dependent variable } \\
\hline $\begin{array}{l}\text { Corporate cash } \\
\text { holding level }\end{array}$ & $\mathrm{CASH}$ & $\begin{array}{l}\text { The ratio of total cash and } \\
\text { cash equivalents to total } \\
\text { assets }\end{array}$ \\
\hline \multicolumn{3}{|c|}{ Independent variables } \\
\hline Firm size & SIZE & The natural log of total assets \\
\hline Leverage & LEV & $\begin{array}{l}\text { The ratio of total debt to total } \\
\text { assets }\end{array}$ \\
\hline $\begin{array}{l}\text { Investment } \\
\text { opportunities }\end{array}$ & MTB & $\begin{array}{l}\text { The ratio of book value of } \\
\text { total assets minus the book } \\
\text { value of equity plus the } \\
\text { market value of assets }\end{array}$ \\
\hline $\begin{array}{l}\text { Liquidity asset } \\
\text { substitutes }\end{array}$ & $\mathrm{LIQ}$ & $\begin{array}{l}\text { The ratio of net working } \\
\text { capital less total cash to total } \\
\text { assets }\end{array}$ \\
\hline $\begin{array}{l}\text { Capital } \\
\text { expenditure }\end{array}$ & CE & $\begin{array}{l}\text { The ratio of capital } \\
\text { expenditure to total assets }\end{array}$ \\
\hline $\begin{array}{l}\text { Dividend } \\
\text { payments }\end{array}$ & DPD & $\begin{array}{l}\text { Dummy variable equal to } \\
\text { one is firm paid a dividend } \\
\text { otherwise equal to zero }\end{array}$ \\
\hline Cash flow & CF & $\begin{array}{l}\text { The ratio of earnings after } \\
\text { interest, dividends, and taxes, } \\
\text { but before depreciation and } \\
\text { amortization for total assets }\end{array}$ \\
\hline $\begin{array}{l}\text { Cash flow } \\
\text { volatility }\end{array}$ & VCF & $\begin{array}{l}\text { Measured as cash flow per } \\
\text { share. }\end{array}$ \\
\hline
\end{tabular}

Table 1. Description of study variables

Source: Al Zoubi (2013). 


\section{RESULTS AND DISCUSSION}

This section presents the results and analysis of the findings of our study. As the use of panel data is commonly associated with problems such as multicollinearity and heteroscedasticity, we performed diagnostic tests to check for these problems.

\subsection{Choice of the appropriate model}

Our study used the likelihood ratio test to choose between the POLS model and the fixed effects model (Table 2). See the hypotheses of the likelihood ratio test below.

H0: The POLS model is better than the fixed effects model.

H1: The fixed effects model is better than POLS model.

Table 2 shows that the results of the likelihood ratio test were significant ( $\mathrm{p}$-value $=0.0000)$. This result means that we reject the POLS model and choose the fixed effects model for this study.
To make a choice between the fixed effects model and the random effects model, we utilized the Hausman test (Table 3). The hypotheses of the test are as follows:

H0: The random effects model is more appropriate than the fixed effects model.

H1: The fixed effects model is more appropriate than the random effects model.

Table 3 shows that the results of this test were significant ( $p$-value $=0.0241)$. Hence, we reject the null hypothesis and conclude that the fixed effects model is the most appropriate of the three models.

Table 2. Likelihood ratio test

\begin{tabular}{|c|c|c|c|}
\hline \multicolumn{4}{|c|}{ Redundant fixed effects tests } \\
\hline \multicolumn{4}{|l|}{ Equation: Untitled } \\
\hline \multicolumn{4}{|c|}{ Test cross-section fixed effects } \\
\hline Effects test & Statistic & d.f & Prob. \\
\hline Cross-section $\mathrm{F}$ & 17.41973 & -16237 & 0.0000 \\
\hline $\begin{array}{l}\text { Cross-section } \\
\text { Chi-square }\end{array}$ & 203.7038 & 16 & 0.0000 \\
\hline
\end{tabular}

Table 3. Hausman test

\section{Correlated random effects - Hausman test}

Equation: untitled

Test cross-section random effects

\begin{tabular}{|c|c|c|c|}
\hline Test summary & Chi-Sq. Statistic & Chi-sq. d. f & Prob. \\
\hline Cross-section random & 17.64069 & 8 & 0.0241 \\
\hline
\end{tabular}

\begin{tabular}{|c|c|c|c|c|}
\hline \multicolumn{5}{|c|}{ Cross-section random effects test comparisons: } \\
\hline Variable & Fixed & Random & Var (Diff.) & Prob. \\
\hline FIRM SIZE & 0.000624 & -0.006236 & 0.000016 & 0.0844 \\
\hline LEVERAGE & 0.001779 & 0.004208 & 0.000042 & 0.7072 \\
\hline LIQUID ASSET SUBSTITUTES & -0.30653 & -0.266111 & 0.000199 & 0.0041 \\
\hline INVESTMENT OPPORTUNITIES & -0.00127 & -0.002813 & 0.000000 & 0.0047 \\
\hline CAPITAL EXPENDITURE & -0.15583 & -0.148723 & 0.000080 & 0.4268 \\
\hline DIVIDEND PAYMENTS & 0.029251 & 0.033782 & 0.000003 & 0.0131 \\
\hline CASH FLOW & -0.00194 & 0.006883 & 0.000089 & 0.3503 \\
\hline CASH FLOW VOLATILITY & 0.000043 & 0.000058 & 0.000000 & 0.0009 \\
\hline
\end{tabular}




\subsection{Descriptive statistics}

The descriptive statistics exhibited in Table 5 indicate that firms in the sample hold high levels of cash equivalent to $16 \%$ of total assets. This percentage is considerably greater than the $5 \%$ for Russian companies, 3.5\% for Chinese companies, $3 \%$ for Indian companies, $2 \%$ for Brazilian firms, $8 \%$ for businesses in the UK and $10 \%$ for US firms (AlNajjar, 2013). Uyar and Kuzey (2014) found an average of $9 \%$ cash to total assets for UK companies. These are the differences in the sample sizes used in these studies. Interestingly, the cash holdings observed for the South African retailers equate to the cash holdings levels of US firms between 1971 and 1994 (Opler et al., 1999) and US industrial companies from 1980 to 2006 (Bates et al., 2009). The statistics also show that the firms in the sample have modest leverage ratios with a mean of $28 \%$, suggesting that the companies do not rely on debt financing. The liquid asset substitutes are minuscule at $3 \%$ of total assets, while capital expenditure is on average $8 \%$ of total assets. The value of a given firm in the sample was found to be on average four times the company's book value.

Plotting the cash holdings trend, the study observed that the firms increased their cash holdings significantly for the four years preceding the 2008 credit crisis before reverting to the pre-crisis means. This surge in post-credit crisis cash holdings explains the precautionary motive for holding cash by firms that endured the adverse consequences of the credit crunch, as lenders were hard pressed to provide finance.

\subsection{Correlation matrix}

Table 6 depicts the correlation matrix of the variables used in this study. As all the associations reported are less than $50 \%$, there are reasonable grounds to conclude that this study is not affected by multicollinearity. The highest correlation is between firm size and dividend payments (47\%), suggesting that larger companies regularly pay dividends.

\subsection{Interpretation of results}

Based on the selected fixed effects model results in Table 4, findings show that the model is significant at the $1 \%$ level with an F statistic of 25.02 .
The $\mathrm{R}^{2}$ value is $71.7 \%$, which is higher than the rejected models, suggesting that the $71.7 \%$ of the variation in the dependent variable understood by using the eight-variable model is employed in this study. Results also show that the coefficient of liquid asset substitutes is negative and significant at the $1 \%$ significance level. This result is also consistent with the trade-off theory, which argues that liquid asset substitutes reduce the dependency on cash holdings, as they can quickly be turned into cash when needed. Other scholars have also found the same result (Kim et al., 2011; Ali et al., 2016).

The study also finds a negative coefficient for capital expenditure significant at the $1 \%$ level. Per the trade-off theory, capital investment improves or increases the asset base of a firm that can be used in future as collateral to obtain credit. Improved borrowing capacity removes the incentives of holding cash, resulting in companies having little cash holdings. The pecking order theory also supports this relationship, with the argument that capital expenditure consumes cash reserves, because firms prefer using internally sourced funds first before they raise debt. This result is also supported by empirical evidence (Riddick and Whited, 2009; Kim et al., 2011; Rehman and Wang, 2013).

Table 4 also shows that dividend payments were found to have a positive relationship with cash holdings, although only significant at the $10 \%$ level. This result is consistent with Ozkan and Ozkan (2004) and Kim et al. (2011). Per the trade-off theory, dividend paying firms are driven by the precautionary motive to hold more cash to avoid missing out on paying dividends, as this tends to send the wrong signal to the market. Under the signaling theory, failure to pay dividends might indicate financial difficulties in the firm, and this might lead to loss of business value.

The study also found a positive relationship (significant at the $1 \%$ level) between cash flow volatility and cash holdings, consistent with the trade-off theory and the findings of Bates et al. (2009) and Wasiuzzaman (2014). The theory argues that cash shortages have adverse effects on firms, as they can be forced to forfeit posi- 
tive NPV investment opportunities. Companies experiencing high cash flow uncertainty will, therefore, be driven by the precautionary motive to hold more cash.

Other variables such as firm size, leverage, investment opportunities and cash flows were found to be insignificant in explaining the cash holdings of the retail companies. Although most studies elsewhere found these variables to be significant, studies in Africa have also found firm size and investment opportunities to be insignificant (Ogundipe et al., 2012).

Table 4. Comparison of results

\begin{tabular}{|c|c|c|c|}
\hline & $\begin{array}{l}\text { Pooled } \\
\text { effect }\end{array}$ & $\begin{array}{l}\text { Random } \\
\text { effect }\end{array}$ & $\begin{array}{l}\text { Fixed } \\
\text { effect }\end{array}$ \\
\hline Firm size & $\begin{array}{c}0.357598 \\
(6.319777)^{* * *}\end{array}$ & $\begin{array}{c}0.225794 \\
(2.467982)\end{array}$ & $\begin{array}{c}0.135670 \\
(1.298693)\end{array}$ \\
\hline Leverage & $\begin{array}{l}-0.019295 \\
(-4.081864)\end{array}$ & $\begin{array}{l}-0.006236 \\
(-0.917942)\end{array}$ & $\begin{array}{c}0.000624 \\
(0.079307)\end{array}$ \\
\hline $\begin{array}{l}\text { Liquid asset } \\
\text { substitute }\end{array}$ & $\begin{array}{c}-0.158935 \\
(-5.929523)^{* * *}\end{array}$ & $(-8.084792) * * *$ & $\begin{array}{l}-0.306528 \\
(-8.561167)^{* * *}\end{array}$ \\
\hline $\begin{array}{l}\text { Investment } \\
\text { opportunities }\end{array}$ & $\begin{array}{l}-0.006242 \\
(-4.700084)^{* * *}\end{array}$ & $(-0.002813$ & $\begin{array}{l}-0.001274 \\
(0.874496)\end{array}$ \\
\hline $\begin{array}{l}\text { Capital } \\
\text { expenditure }\end{array}$ & $\begin{array}{c}-0.174561 \\
(-2.280472)^{* *}\end{array}$ & $\begin{array}{l}-0.148723 \\
(-2.466833)^{* *}\end{array}$ & $\begin{array}{c}-0.155829 \\
(-2.556733)^{* * *}\end{array}$ \\
\hline $\begin{array}{l}\text { Dividend } \\
\text { payments }\end{array}$ & $\begin{array}{c}0.075992 \\
(3.523105)^{* * *}\end{array}$ & $\begin{array}{c}0.033782 \\
(2.040547)^{* *}\end{array}$ & $\begin{array}{c}0.029251 \\
(1.756213)^{*}\end{array}$ \\
\hline Cash flow & $\begin{array}{c}0.064469 \\
(1.489277)\end{array}$ & $\begin{array}{c}0.006883 \\
(0.182307)\end{array}$ & $\begin{array}{l}-0.001944 \\
(-0.049961)\end{array}$ \\
\hline $\begin{array}{l}\text { Cash flow } \\
\text { volatility }\end{array}$ & $\begin{array}{c}0.000103 \\
(9.766329)\end{array}$ & $\begin{array}{c}0.000058 \\
(5.090172)^{* * *}\end{array}$ & $\begin{array}{c}0.000043 \\
(3.527606)^{* * *}\end{array}$ \\
\hline Constant & $\begin{array}{c}0.357598 \\
(6.319777)^{* * *}\end{array}$ & $\begin{array}{c}0.225794 \\
(2.467982)^{* *}\end{array}$ & $\begin{array}{c}0.135670 \\
(1.298693)\end{array}$ \\
\hline $\mathrm{R}^{2}$ & 0.384167 & 0.309084 & 0.716991 \\
\hline $\begin{array}{l}\text { Number of } \\
\text { observations }\end{array}$ & 262 & 262 & 262 \\
\hline
\end{tabular}

Notes: Table 4 above presents regression results from the pooled effect, random effect, and fixed effect models, respectively. For each independent variable, each model gives the regression coefficient with the $t$-statistics in parentheses.

${ }^{*}, *$ and ${ }^{* * *}$ indicate the significance of the results at $10 \%, 5 \%$, and $1 \%$ levels, respectively.

While the analysis utilized three regression models, after performing the likelihood test and the Hausman test, the fixed effects model was found to be the most appropriate. The results from the fixed effects model showed that liquid asset substitutes and capital expenditure have an adverse impact on cash holdings, while dividend payment and cash flow volatility have a positive impact on cash holdings.

The study brings to the fore some academic observations. For instance, research in the developed countries shows that larger firms tend to hold less cash because of the ease with which they can access and negotiate for relatively cheap external financing. Most studies in developed countries also show that firms with high investment opportunities are driven by the precautionary motive to hold more cash. Our study, however, found both firm size and investment opportunities to be insignificant drivers of the cash holdings by companies. These results are consistent with those from the study conducted by Ogundipe et al. (2012) in Nigeria, suggesting that within emerging countries, firm size and investment opportunities do not significantly influence corporate cash holdings. Second, our results showed that liquid asset substitutes and capital expenditure have an adverse impact on retail business cash holdings. These findings are consistent with other studies in other countries (Bates et al., 2009; Kim et al., 2011; Ali and Yousaf, 2013). An indication that South African retail firms also reduce cash holdings when they have high liquid asset substitutes that can quickly become cash without incurring significant transaction costs. Capital expenditure by these companies improves their capital asset base that they will eventually use as collateral to boost their borrowing capacity (Bates et al., 2009). Firms with lower capital expenditure will be financially constrained with limited credit access and will, therefore, tend to hold more cash. Third, South African retail firms hold more cash as a precaution against missing out on dividend payments. Dividend payments are important to South African companies, as they signal the businesses' prospects to the capital markets.

The market views a business that fails to keep up with dividend payments as unstable, and this will hurt its share price. Directors of South African retail companies get rewarded with generous stock options. As such, the positive relationship between dividend payments and cash holdings 
might signify the presence of the agency conflict, as managers seek to manage stock prices by maintaining dividend payments even when it is not in the best interest of the shareholders. Finally, our study found that cash flow volatility motivates firms to hold more cash as a precaution against a rainy day. This variable was not included in the studies conducted by Kim et al. (2011), Al- Najjar (2013), Ali, Ullar and Ullar (2016) and other studies that utilized panel data analysis, because the measure of cash flow volatility commonly used in the literature (standard deviations of cash flows divided by mean total assets) gave a monotonous figure per company for the study period and this is not compatible with panel data analysis. This study used cash flow per share to measure the volatility of cash flows. The inclusion of this firm-specific variable furthers the understanding of corporate cash holdings behavior (Kim et al., 2011).

\section{CONCLUSION}

Corporate cash holdings are a major topic in accounting and finance and have attracted huge debate amongst academics. However, the ongoing discussion has not sufficiently addressed the cash holdings behavior in emerging economies. Therefore, the aim of this study is to provide new empirical evidence on the firm-specific determinants of cash holdings in an emerging economy. Data collected from a sample of 17 JSE listed South African retail firms were from the year 2000 to 2015. Data were from the INET BFA database. Three regression models were used to analyze the data, although the fixed effects regression model was found to be the most accurate for this study. Results obtained in this study are consistent with evidence in available corporate cash holding literature. A total of eight variables - firm size, leverage, liquid asset substitutes, investment opportunities, capital expenditure, dividend payments, cash flows and cash flow volatility - were studied to ascertain whether they have significant explanatory power on the cash holdings levels of the companies. Our findings show that dividend payments and cash flow volatility positively influence retail cash holdings, whereas liquid asset substitutes and capital expenditure exert a negative influence, whereas firm size, leverage, investment opportunities and cash flows were all found to have an insignificant impact on the cash holdings of retail companies.

Our study also has practical implications to most stakeholders in the retail firms. High corporate cash holdings are often associated with potential agency conflict. The free cash flow theory specifically argues that managers often view cash holdings as free cash flows and often misappropriate them for private benefits. A good understanding of the nexus between various firm-specific factors and the company's cash holdings, stakeholders can pass informed judgments regarding the cash balances of the firms of their choice. Therefore, based on the findings of our study, an investor can reasonably conclude that a company with high liquid asset substitutes and high capital expenditure should retain lower cash holdings. If, for some reason, a firm with high liquid asset substitutes and high capital investment also has large cash holdings, this might be a signal of a possible agency conflict. Similarly, astute retail managers will want to avoid holding excessive cash reserves as this might attract scrutiny from the capital markets.

Limitations. This study only focuses on a sample of South African retail firms and, as such, the findings can only be generalized to the entirety of the companies listed on the JSE. Also, our study excluded retail companies with missing years from the study sample. While this gives us a balanced panel, leaving out companies with missing observations gives rise to survivorship bias.

Recommendations. Future research should look at other sectors other than the retail sector to understand the drivers of cash holdings in other industries. The role of internal corporate governance mechanisms such as the structure, size, composition, and independence of the board of directors, on cash holdings should be investigated. 


\section{REFERENCES}

1. Afza, T., \& Adnan, S. (2007). Determinants of corporate cash holdings: A case study of Pakistan. Proceedings of Singapore Economic Review Conference (SERC) 01.

2. Ali, A., \& Yousaf, S. (2013). Determinants of Cash holding in German Market. IOSR Journal of Business and Management (IOSRJBM), 12(6), 28-34.

3. Ali, S., Ullah, M., \& Ullah, N. (2016). Determinants of Corporate Cash Holdings: A Case of Textile Sector in Pakistan. Retrieved from https://papers. ssrn. com/sol3/ papers.cfm?abstract_id $=2728200$

4. Almeida, H., Campello, M., \& Weisbach, M. S. (2004). The cash flow sensitivity of cash. The Journal of Finance, 59(4), 1777-1804.

5. Al-Najjar, B. (2013). The financial determinants of corporate cash holdings: Evidence from some emerging markets. International Business Review, 22(1), 77-88.

6. Al-Najjar, B., \& Belghitar, Y. (2011). Corporate cash holdings and dividend payments: evidence from simultaneous analysis. Managerial and Decision Economics, 32(4), 231-241.

7. Al Zoubi, T. (2013). Corporate cash-holding decisions: Amman stock exchange. Doctoral dissertation: School of Social Sciences Theses. Retrieved from http://v-scheiner. brunel. ac. uk/bitstream/2438/7360/1/ FulltextThesis. pdf (last accessed 24 April 2017).

8. Bates, T. W., Kahle, K. M., \& Stulz, R. M. (2009). Why do US firms hold so much more cash than they used to? The Journal of Finance, 64(5), 1985-2021.

9. Bigelli, M., \& Sánchez-Vidal, J. (2012). Cash holdings in private firms. Journal of Banking \& Finance, 36(1), 26-35.

10. Boubaker, S., Derouiche, I., \& Nguyen, D. K. (2015). Does the board of directors affect cash holdings? A study of French listed firms. Journal of Management \& Governance, 19(2), 341-370.
11. D’Mello, R., Krishnaswami, S., \& Larkin, P. J. (2008). Determinants of corporate cash holdings: Evidence from spin-offs. Journal of Banking \& Finance, 32(7), 12091220.

12. Daher, M. (2010). The Determinants of Cash Holdings in UK Public and Private Firms. Dissertation, Lancaster University Business School, Lancaster University.

13. Đinh Phạm Anh, T. (2013). Determinants of corporate cash holdings: A study of listed manufacturing companies in Vietnam. Dissertation, Ho Chi Minh City International University.

14. Dittmar, A., \& Mahrt-Smith, J. (2007). Corporate governance and the value of cash holdings. Journal of Financial Economics, 83(3), 599-634.

15. Dittmar, A., Mahrt-Smith, J., \& Servaes, H. (2003). International corporate governance and corporate cash holdings, Journal of Financial and Quantitative Analysis, 38(01), 111-133.

16. Drobetz, W., \& Grüninger, M. C. (2007). Corporate cash holdings: Evidence from Switzerland. Financial Markets and Portfolio Management, 21(3), 293-324.

17. Faulkender, M., \& Wang, R. (2006). Corporate financial policy and the value of cash. The Journal of Finance, 61(4), 1957-1990.

18. Ferreira, M. A., \& Vilela, A. S. (2004). Why do firms hold cash? Evidence from EMU countries. European Financial Management, 10(2), 295-319.

19. Fischer, M. L., Marsh, T., \& Brown T. A. (2014). Cash Holdings of $S$ \& P Firms Over the Past Decade. Accounting and Finance Research, 3(3), 143-150.

20. Foley, C. F., Hartzell, J. C., Titman, S., \& Twite, G. (2007). Why do firms hold so much cash? A tax-based explanation. Journal of Financial Economics, 86(3), 579-607.
21. Gill, A., \& Shah, C. (2012). Determinants of corporate cash holdings: Evidence from Canada. International Journal of Economics and Finance, 4(1), 70-79.

22. Gomes, M. D. S. (2012). The financial determinants of corporate cash holdings: evidence from growing firms. Dissertation (Universidade da Beira Interior).

23. Grinstein, Y., Weinbaum, D., \& Yehuda, N. (2008). Perks and excess: Evidence from the new executive compensation disclosure rules. Unpublished working paper, Cornell University. Johnson School Research Paper Series: 04-09.

24. Guney, Y., Ozkan, A., \& Ozkan, N. (2007). International evidence on the non-linear impact of leverage on corporate cash holdings. Journal of Multinational Financial Management, 17(1), 45-60.

25. Hardin III, W. G., Highfield, M. J., Hill, M. D., \& Kelly, G. W. (2009). The determinants of REIT cash holdings. The Journal of Real Estate Finance and Economics, 39(1), 39-57.

26. Harford, J. (1999). Corporate cash reserves and acquisitions. The Journal of Finance, 54(6), 19691997.

27. Iskandar-Datta, M. E., \& Jia, Y. (2014). Investor protection and corporate cash holdings around the world: new evidence. Review of Quantitative Finance and Accounting, 43(2), 245-273.

28. Islam, S. (2012). Manufacturing Firms' Cash Holding Determinants: Evidence from Bangladesh. International Journal of Business and Management, 7(6), 172-184.

29. Jensen, M. C. (1986). Agency cost of free cash flow, corporate finance, and takeovers. Corporate Finance, and Takeovers. American Economic Review, 76(2), 323-329.

30. Kariuki, S. N., Namusonge, G. S., and Orwa, G. O. (2015). Determinants of corporate cash holdings: evidence from private 
manufacturing firms in Kenya. International Journal of Advanced Research in Management and Social Sciences, 4(6), 15-33.

31. Kim, C., Mauer, D. C., \& Sherman, A. E. (1998). The determinants of corporate liquidity: Theory and evidence. Journal of Financial and Quantitative Analysis, 33(3), 335-359.

32. Kim, J., Kim, H., \& Woods, D. (2011). Determinants of corporate cashholding levels: An empirical examination of the restaurant industry. International Journal of Hospitality Management, 30(3), 568-574.

33. Mikkelson, W. H., \& Partch, M. M. (2003). Do persistent large cash reserves hinder performance? Journal of Financial and Quantitative Analysis, 38(02), 275-294.

34. Miller, M. H., \& Orr, D. (1966). A Model of the Demand for Money by Firms. The Quarterly Journal of Economics, 80(3), 413-435.

35. Myers, S. C. (1977). Determinants of corporate borrowing. Journal of Financial Economics, 5(2), 147-175.

36. Myers, S. C., \& Majluf, N. S. (1984). Corporate financing and investment decisions when firms have information that investors do not have. Journal of Financial Economics, 13(2), 187-221.

37. Ogundipe, L. O., Ogundipe, S. E., \& Ajao, S. K. (2012). Cash holding and firm characteristics: Evidence from Nigerian emerging market. Journal of Business Economics and Finance, 1(2), 45-58.
38. Opler, T., Pinkowitz, L., Stulz, R., \& Williamson, R. (2001). Corporate cash holdings. Journal of Applied Corporate Finance, 14(1), 55-67.

39. Opler, T., Pinkowitz, L., Stulz, R., \& Williamson, R. (1999). The determinants and implications of corporate cash holdings. Journal of Financial Economics, 52(1), 3-46.

40. Ozkan, A., \& Ozkan, N. (2004). Corporate cash holdings: An empirical investigation of UK companies. Journal of Banking and Finance, 28(9), 2103-2134.

41. Riddick, L. A., \& Whited, T. M. (2009). The corporate propensity to save. The Journal of Finance, 64(4), 1729-1766.

42. Saddour, K. (2006). The determinants and the value of cash holdings: Evidence from French firms. CEREG, 1-33. Retrieved from http://www. cereg. dauphine. fr/cahiers_rech/cereg200606.pdf (accessed 6 August 2015).

43. Subramaniam, V., Tang, T. T., Yue, H., \& Zhou, X. (2011). Firm structure and corporate cash holdings. Journal of Corporate Finance, 17(3), 759-773.

44. Thanatawee, Y. (2011). Lifecycle theory and free cash flow hypothesis: Evidence from dividend policy in Thailand. International Journal of Financial Research, 2(2), 52-60.

45. Tong, Z. (2006). Risk reduction as a CEO's motive for corporate cash holdings. Retrieved from Retrieved from SSRN 1031087 (accessed 12 November 2016).
46. Tsuji, C. (2011). An international survey of the evidence of the pecking order theory of corporate financing. Business and Economic Research, 1(1). doi: http://dx. doi. org/10. 5296/ber. vli1. 952 (accessed 6 August 2015).

47. Uyar, A., \& Kuzey, C. (2014). Determinants of corporate cash holdings: evidence from the emerging market of Turkey. Applied Economics, 46(9), 1035-1048.

48. Venkiteshwaran, V. (2011). Partial adjustment toward optimal cash holding levels, Review of Financial Economics, 20(3), 113-121.

49. Wang, M. (2015). Corporate cash holdings and adjustment behavior in Chinese firms: An empirical analysis using Generalized Method of Moments. Australasian Accounting, Business, and Finance Journal, 9(4), 20-37.

50. Wasiuzzaman, S. (2014). Analysis of corporate cash holdings of firms in Malaysia. Journal of Asia Business Studies, 8(2), 118-135.

51. Yu, Y. Lee, Y., \& Fok, RC. (2015). Speculative motive for holding cash and high-interest entrusted loans. Retrieved from SSRN 2649970.

52. Zhang, Q. 2016. Corporate governance, institutional investors, and firm performance: A comparative study of South Africa and China (Doctoral dissertation, Stellenbosch: Stellenbosch University). Retrieved from https://scholar. sun. ac. za/ handle/10019. 1/100105 (accessed 24 April 2017). 
APPENDIXES

Table 5. Descriptive statistics

\begin{tabular}{|c|c|c|c|c|c|c|c|c|c|}
\hline & $\begin{array}{l}\text { CASH } \\
\text { HOLDINGS }\end{array}$ & FIRM_SIZE & LEVERAGE & $\begin{array}{l}\text { LIQUID ASSET } \\
\text { SUBSTITUTES }\end{array}$ & $\begin{array}{l}\text { INVESTMENT } \\
\text { OPPORTUNITIES }\end{array}$ & $\begin{array}{c}\text { CAPITAL } \\
\text { EXPENDITURE }\end{array}$ & $\begin{array}{l}\text { DIVIDEND } \\
\text { PAYMENTS }\end{array}$ & CASH_FLOW & $\begin{array}{l}\text { CASH FLOW } \\
\text { VOLATILITY }\end{array}$ \\
\hline Mean & 0.161113 & 14.28036 & 0.286968 & 0.039152 & 4.042748 & 0.084676 & 0.877863 & 0.167521 & 483.7207 \\
\hline Median & 0.133765 & 14.54490 & 0.153209 & 0.026755 & 2.795000 & 0.064813 & 1.000000 & 0.171571 & 269.2450 \\
\hline Maximum & 0.497038 & 17.59788 & 0.936523 & 0.555658 & 45.15000 & 0.756355 & 1.000000 & 0.705104 & 3327.920 \\
\hline Minimum & 0.000000 & 7.349874 & 0.000000 & -0.633236 & 0.000000 & -0.008072 & 0.000000 & -1.343188 & -165.6500 \\
\hline Std. dev. & 0.122410 & 1.748886 & 0.290580 & 0.260038 & 4.925757 & 0.087889 & 0.328071 & 0.158371 & 589.8184 \\
\hline Skewness & 0.677848 & -0.487650 & 0.777977 & 0.051726 & 3.720435 & 4.114068 & -2.307949 & -3.165999 & 2.038104 \\
\hline Kurtosis & 2.783626 & 3.040639 & 2.098972 & 2.500083 & 25.28646 & 26.07477 & 6.326630 & 33.86351 & 7.809906 \\
\hline Jarque-Bera & 20.57496 & 10.40206 & 35.29186 & 2.845095 & 6026.576 & 6551.607 & 353.4052 & 10836.43 & 433.9447 \\
\hline Probability & 0.000034 & 0.005511 & 0.000000 & 0.241099 & 0.000000 & 0.000000 & 0.000000 & 0.000000 & 0.000000 \\
\hline Sum & 42.21161 & 3741.455 & 75.18562 & 10.25778 & 1059.200 & 22.18515 & 230.0000 & 43.89053 & 126734.8 \\
\hline Sum sq. dev. & 3.910897 & 798.2953 & 22.03801 & 17.64872 & 6332.663 & 2.016111 & 28.09160 & 6.546230 & 90798194 \\
\hline Observations & 262 & 262 & 262 & 262 & 262 & 262 & 262 & 262 & 262 \\
\hline
\end{tabular}

Note: Table 1 shows the descriptive statistics for the variables described below. Data were for the period from 2000 to 2015 . Cash holdings are the ratio of total cash and cash equivalents to total assets. Firm size is the natural logarithm of total assets. Leverage is the ratio of total debts to total assets. Investment opportunities are measured as the market to book ratio. Liquid asset substitutes are the ratio of net working capital less total cash to total assets. Capital expenditure is the proportion of capital expenditure to total assets. The dividend payment Liquid asset substitutes are the ratio of net working capital less total cash to total assets. Capital expenditure is the proportion of capital expenditure to total assets. The dividend payment
measures by means on a dummy variable where the dummy variable takes the value of one in the year of dividend payment; otherwise, it takes the value of zero. Cash flow is the ratio of earnings after interest, dividends, and taxes, but before depreciation and amortization for total assets. Cash flow volatility is the cash flow per share. 
Table 6. Correlation matrix

\begin{tabular}{|c|c|c|c|c|c|c|c|c|}
\hline & CASH_FLOW & FIRM_SIZE & LEVERAGE & $\begin{array}{l}\text { LIQUID ASSET } \\
\text { SUBSTITUTES } \\
\end{array}$ & $\begin{array}{c}\text { INVESTMENT } \\
\text { OPPORTUNITIES } \\
\end{array}$ & $\begin{array}{c}\text { CAPITAL } \\
\text { EXPENDITURE } \\
\end{array}$ & $\begin{array}{l}\text { DIVIDEND } \\
\text { PAYMENTS } \\
\end{array}$ & $\begin{array}{l}\text { CASH FLOW } \\
\text { VOLATILITY } \\
\end{array}$ \\
\hline CASH_FLOW & 1 & $0.32016634 \ldots$ & $-0.0423940 \ldots$ & $0.11074434 \ldots$ & $0.09227317 \ldots$ & $0.20145959 \ldots$ & $0.20251322 \ldots$ & $0.05519217 \ldots$ \\
\hline FIRM_SIZE & $0.32016634 \ldots$ & 1 & $0.39431477 \ldots$ & $-0.1958225 \ldots$ & $0.28071873 \ldots$ & $0.10738709 \ldots$ & $0.47560131 \ldots$ & $0.04638592 \ldots$ \\
\hline LEVERAGE & $-0.0423940 \ldots$ & $0.39431477 \ldots$ & 1 & $-0.2625259 \ldots$ & $0.10983291 \ldots$ & $0.21241214 \ldots$ & 0.01020397... & $0.00937492 \ldots$ \\
\hline $\begin{array}{l}\text { LIQUID ASSET } \\
\text { SUBSTITUTES }\end{array}$ & $0.11074434 \ldots$ & $-0.1958225 \ldots$ & $-0.2625259 \ldots$ & 1 & $-0.2304636 \ldots$ & $-0.3053303 \ldots$ & $-0.0782952 \ldots$ & $0.18132152 \ldots$ \\
\hline $\begin{array}{l}\text { INVESTMENT } \\
\text { OPPORTUNITIES }\end{array}$ & $0.09227317 \ldots$ & $0.28071873 \ldots$ & $0.10983291 \ldots$ & $-0.2304636 \ldots$ & 1 & $-0.0274635 \ldots$ & $0.21349726 \ldots$ & $-0.1385986 \ldots$ \\
\hline $\begin{array}{l}\text { CAPITAL } \\
\text { EXPENDITURE }\end{array}$ & $0.20145959 \ldots$ & $0.10738709 \ldots$ & $0.21241214 \ldots$ & $-0.3053303 \ldots$ & $-0.0274635 \ldots$ & 1 & $0.01358947 \ldots$ & $-0.0004073 \ldots$ \\
\hline $\begin{array}{l}\text { DIVIDEND } \\
\text { PAYMENTS }\end{array}$ & $0.20251322 \ldots$ & $0.47560131 \ldots$ & $0.01020397 \ldots$ & $-0.0782952 \ldots$ & $0.21349726 \ldots$ & $0.01358947 \ldots$ & 1 & $-0.0190997 \ldots$ \\
\hline $\begin{array}{l}\text { CASH FLOW } \\
\text { VOLATILITY }\end{array}$ & $0.05519217 \ldots$ & $0.04638592 \ldots$ & $0.00937492 \ldots$ & $0.18132152 \ldots$ & $-0.1385986 \ldots$ & $-0.0004073 \ldots$ & $-0.0190997 \ldots$ & 1 \\
\hline
\end{tabular}

Note: WTable 2 exhibits the correlations between the variables used in the study. Data were for the period from 2000 to 2015 . Cash holdings are the ratio of total cash and cash equivalents to total assets. Firm size is the natural logarithm of total assets. Leverage is the ratio of total debts to total assets. Investment opportunities are measured as the market to book ratio. Liquid asset substitutes are the ratio of net working capital less total cash to total assets. Capital expenditure is the proportion of capital expenditure to total assets. The dividend payment measures a dummy variable where the dummy variable takes the value of one in the year a dividend is paid; otherwise, it takes the value of zero. Cash flow is the ratio of earnings after interest, dividends, and taxes, but before depreciation dummy variable takes the value of one in the year a dividend is paid; otherwis
and amortization for total assets. Cash flow volatility is cash flow per share 